УДК 791.633(477)-051Віт:378.6:[792+791](477.411)КНУТКіТ](045)

ORCID ID: https://orcid.org/0000-0002-8447-796X

\author{
Чхатарашвілі-Петраш Інга Теймуразівна, \\ заступник директора з освітньої роботи Інституту \\ екранних мистецтв, старший викладач кафедри \\ кінознавства. Київський національний університет театру, \\ кіно і телебачення імені І. К. Карпенка-Карого, Київ. \\ Inha Chkhatarashvili-Petrash, \\ Lector of cinematology Departament, \\ Kyiv National I. K. Karpenko-Karyi Theatre, Cinema and \\ Television University, Kyiv.
}

\title{
ВАСИЛЬ ВІТЕР: МИСТЕЦТВО БУТИ ПЕДАГОГОМ
}

Анотація. Стаття присвячена висвітленню педагогічної діяльності відомого українського режисера В. Вітра, яка заслуговує уваги не менше, ніж його відомі кінороботи та акторська майстерність. Авторка аналізує основні принципи педагогічної системи майстра (традиції та правила, саморозвиток, системність, відповідальність та ін.), що дали змогу сформувати оригінальну майстерню режисури телебачення в Інституті екранних мистецтв Київського національного університету театру, кіно і телебачення імені I. К. Карпенка-Карого. Сьогодні майстерня переросла у «вітрівську школу», яку можна вважати зразковою моделлю взаємодії педагога і студента мистецького вишу.

Ключові слова: Василь Вітер, Віталій Савчук, вітрівська школа, викладач, майстерня, режисер.

Постановка проблеми та актуальність дослідження. Інститут екранних мистецтв Київського національного університету театру, кіно і телебачення імені І. К. Карпенка-Карого славиться відомими діячами телебачення та кіно, які мають значний досвід роботи і викладання. На жаль, в українському мистецтвознавстві проблематика педагогіки у сфері екранних мистецтв не надто розвинена. Так, є дослідження української кіношколи О. В. Безручка, узагальнені в його докторській дисертації, проте дослідник охоплює хронологічні межі 1930-1960-х років. Утім, і в подальший період у стінах Університету викладали і викладають яскраві особистості, педагогічний досвід яких повчальний для всіх, а особливо для молодого покоління викладачів. Актуальність статті «Василь Вітер: мистецтво бути педагогом» полягає у дідизні педагогічного мистецтва для здобувачів вищої освіти, тому що мистецтво виховання, як і будь-яке мистецтво, легше перейняти, ніж зрозуміти. Авторка зосереджує увагу читача на тому, що можна запозичити: ідеї, розробки, погляди, вчинки.

Mema cmammi - визначити й охарактеризувати провідні принципи педагогічної системи Василя Вітра, що обумовила цікавий і плідний період становлення, формування і розвитку майстерні режи- сури телебачення в Інституті екранних мистецтв Київського національного університету театру, кіно і телебачення імені І. К. Карпенка-Карого.

Виклад основного матеріалу. Український режисер, завідувач кафедри режисури телебачення, доцент, заслужений діяч культури України Василь Вітер народився 16 червня 1951 року в селі Великополовецьке у Сквирському (нині Білоцерківському) районі Київської області.

У 1972 році закінчив акторське ремесло у Київському державному інституті театрального мистецтва імені I. К. Карпенка-Карого в учня Леся Курбаса, професора Михайла Верхацького та Миколи Мерзлікіна. Принципами майстрів було продовження традицій школи Леся Курбаса, а також «не нав' язувати власні смаки, а підказувати шляхи до “відкриття" акторів, художників, письменників» (Безручко О., 2017, с. 84). Потім Василь Вітер працює актором першої категорії у Житомирському українському драматичному театрі та у Волинському обласному українському драмтеатрі імені Т. Г. Шевченка. А у 1976 році вступає на режисерський курс у майстерню українського кінорежисера В. Кісіна, який був не просто учнем, а й послідовником М. Верхацького: залучав своїх студентів до педагогічної діяльності, допомагав їм знаходити власний 
творчий шлях, а також, всупереч театральним традиціям інституту, заснував свій стиль- «уміння використовувати обставини і поєднати їх зі специфічним простором драматургії видовища (суспільне очікування теми і іiі вирішення саме таким естетично-емоційним способом)» (Безручко О., 2017, с. 84).

Педагогічний метод В. Вітра тісно пов'язаний iз тим впливом режисерської особистості і педагогіки, який він отримав за часів своєї театральної юності. Проте він не копіює, а продовжує в знак пошани і вдячності традиції наставників і в своїй майстерні, органічно об'єднує режисерське і акторське мистецтво, створюючи свою школу, будуючи свою «систему». «Моя справа навчити їх професії й не зробити схожими на мене, Віталія Савчука чи Миколу Мерзлікіна, залишити їхнє світовідчуття, погляд, не поламати їхнє художнє мислення», -зазначає Василь Вітер.

У педагогічній роботі Василь Петрович не послуговується сталими рецептами, але має свої позиції, свої погляди, свої методи навчання, завдяки яким «придивляється» до студентів. Кожному зі своїх учнів, які пройшли навчання в його майстерні в різні роки, він намагається допомогти відкрити щось нове в собі самому. Він вчить актора розмовляти $з$ глядачем, вчить умінню перевтілюватися, знаходити прийоми, важелі, за допомогою яких можна передати режисерські думки, навчає по-справжньому бачити весь процес створення і вистави, і фільму, бути відповідальним та шанувати традиції, вчить цінувати свою націю і українську культуру.

Згадуючи роки свого режисерського становлення, В. Вітер із вдячністю говорить про ту школу, яку він отримав у Київському державному інституті театрального мистецтва імені І. К. КарпенкаКарого, про тих педагогів, які виявилися чуйними, терплячими, прищепили йому відданість до професії. Але найбільше своїми досягненнями Василь Петрович зобов'язаний самому собі, неспокою своєї натури, постійному самоконтролю, непересічній волі, жадобі самовдосконалення.

У режисера майже немає вільного часу «в чистому вигляді»: його життя - це постійний рух (культурний, політичний, творчий, духовний) все це для нього і праця, і відпочинок. Але, попри значну зайнятість у режисурі, вже понад 20 років він викладає у Київському національному університеті театру, кіно і телебачення імені I. К. Карпенка-Карого, виховує підростаюче покоління і готує творчі й педагогічні кадри не лише для нашого закладу, а й для країни загалом.
Отже, у педагогічній практиці Василь Вітер виробив свою результативну манеру викладання. Звернемося до найбільш, на наш погляд, важливих.

\section{1. Традиції та правила}

Щасливчики, які потрапляють у його майстерню, проходять невелике посвячення, точніше, знайомляться 3 традиціями майстерні, що тривають ще від школи Леся Курбаса. Перше, про що повинні пам'ятати студенти, - це три правила майстерні: правда, дисципліна й українська мова. На перший погляд, ці звичаї можуть налякати або викликати розгубленість у студента. Але по суті ці три правила можна віднести до будь-якого екранного видовища в Україні, до будь-якого контенту в Ютубі, до будь-якого продукту, що його створюють і дивляться на гаджетах. Створюючи екранне видовище, студент повинен бути правдивим і шукати істинуу часи фейків і симулякрів слід щодня боротися за правду. Студент повинен бути дисциплінованим i вимогливим до себе. I найголовніше,-він зможе інтегруватися у сучасний соціокультурний простір тільки через українську мову. Кожен студент у процесі роботи з майстром усвідомлює, що саме він i $є-$-український народ, він повинен бути собою, нести свою культуру, свій фольклор, обряди і традиції. І лише тоді тебе почують і побачать.

Друга цікавинка майстерні: тільки тут усі вітаються так: «Доброї роботи!» Ірина Правило поділилася:

Коли промовляєш або чуєш це словосполучення між студентами або педагогами, ти моментально немов причащаєшся. Виникає відчуття відповідальності до того, чим ти займаєшся, ніби ти доторкаєшся до чогось цінного: до традиції, до школи, до джерела. (Чхатарашвілі-Петраш I., 2021, 3 архіву авторки).

I провідником цих традицій від школи Леся Курбаса і до сьогодні є Василь Петрович Вітер. Кожен, хто потрапляє до нього в майстерню, унікальний в режисурі, світосприйнятті, своєму досвіді. Василь Вітер дає можливість дізнатися, відчути, доторкнутися до школи, а також він хоче, щоб ці правила, ці традиції жили в його студентах, тому що вони виявляють, розкривають в них найкращі людські та творчі якості.

Третя особливість майстерні: на першій парі Василь Петрович каже своїм студентам: «Я ваш колега»,- ставлячи їх нарівні з собою, незважаючи на те, що перед ним насправді жовтороті пташенята. Він дає учням таку установку з перспективою на майбутнє - і це їх надихає. Студенти, які зможуть відчути, прийняти і натхненно розвивати ці правила-закони майстерні, стають глибоко знаю- 
чими, ерудованими фахівцями, яким є що сказати світові.

\section{2. Культура}

Головною особливістю вітрівської школи є формування культури студентської молоді, й робить він це насамперед за допомогою мистецтва. Уже на першій лекції він просить своїх студентів говорити винятково українською мовою, тому що, за твердженням В. Вітра, мова є основою формування особистості й усвідомлення національної самоідентифікації. У фільмах і виставах студентів Вітер-педагог робить акцент на українську літературу, відомих українських діячів, український народ для того, щоб у студентів розвивалися моральні якості. Знання української мови, української літератури, фольклору і традицій допомагають розвинути в них чуттєвість такого рівня, яка потрібна режисерові. Своєю працею Василь Петрович примножує і зберігає духовну спадщину, народні традиції, несе українську культуру в широкі маси.

\section{3. Системність}

Це важливий практичний підхід у режисурі. Для того щоб досягти основного ефекту в фільмі чи виставі В. Вітер уміє поєднати аналіз і синтез, він глибоко «занурюється» в деталі, аналізує їх, оцінює художні засоби, бачить, наскільки вони адекватно використані, як відіграють свою роль в епізоді, а $з$ побаченого може вчасно «виринути» 3 непоєднуваних деталей, художніх засобів. Наприклад, при перегляді відеофільму педагог бачить, як в одному епізоді виникає певна суперечність між діями художніх засобів, які не є драматургічно зумовленими, коли актори грають одну ситуацію, а побудова кадру оператором повністю суперечить завданню, що його вирішують актори. I це може заважати глядачеві зрозуміти головну ідею фільму, тому що працює в зіткненні, руйнуючи весь задум фільму. Це бачить В. Вітер і підказує студентові вихід, схему або художні засоби, якими цей задум можна реалізувати, розкрити.

\section{4. Саморозвиток}

Керівник майстерні не просто вчить студентів, а й сам вчиться разом з ними. Наприклад, коли майстер і його учні створюють фільм, дія якого відбувається в сьогоденні або минулому, він занурюється в різні пласти сучасного культурного поля. І це стосується не лише літератури, поезії або музики, популярної серед сучасної молоді, а й різних векторів цифрової епохи, яка прийшла в наше життя. В. Вітер перебуває всередині цього процесу, що дає йому можливість «не випадати» iз сучасного контексту, бачити найновітніші зміни реального часу. Студенти допомагають йому йти в ногу із сучасним світом, вони наповнюють новим сенсом його життя.

\section{5. Ретельна праця}

В. П. Вітер працює захоплено: зі студентами проживає, переживає все, що відбувається 3 ними щодня, він віддає всього себе в роботі й спілкуванні 3 ними. Кожного дня він і його студенти працюють пліч-о-пліч, педагог допомагає їм монтувати фільми для курсових і дипломних робіт. На моє запитання: «А хіба самі вони не вміють?»-він відповідає з любов’ю і посмішкою: «Вони ще недосвідчені. Не бачать всієї картини відразу, я мушу направити їх, розповісти і пояснити». Василь Вітер передає студентам свій багатющий режисерський і сценічний досвід, знання і мудрість. Він вважає, що найважливішим завданням режисера є вміння розкрити задум драматурга через мистецтво актора.

Ще однією визначною рисою Вітра-педагога є його стиль викладання - спрямовуючий стиль. Василь Петрович дозволяє своїм студентам виявляти ініціативу, і сам залишається досить м'яким щодо оцінки їхньої креативної волі. Особливо це спрацьовує, коли студент не впевнений щодо свого творчого рішення, і саме для того, аби не загнати в кут, йому дається більше простору. Але бувають моменти, коли майстер працює зі студентом над першою версією фільму - таким собі «сирцем». Ось тут починається процес перетворення студента в режисера. Починається ретельна робота над кожним кадром: які є зайвими, а які можуть збагатити фільм. Своїм досвідом режисер Василь Вітер оцінює не те, як ці кадри отримані, а який вигляд ці кадри мають, як вони можуть збагатити фільм, бо кожен кадр має працювати на тему фільму. Василь Петрович глибоко оцінює роботу студента та допомагає йому побачити їі потенційний фінальний результат. Під час такої роботи у студента виробляється власне бачення і розуміння, як відокремити своє особисте ставлення до кадру від того, що потребує картина.

Однією із заповідей у наставництві В. Вітра $\epsilon$ розвиток елітарності студента - визнання їхніх рівних можливостей до сприйняття і розуміння («Ви читали? Ви бачили?»), напуттям і порадами («Не потрібно кожного разу, після кожного почутого зауваження переробляти текст реферату, сценарію, етюду. Відстоюйте свій погляд, свою ідею»). Якщо щось задано, то все буде обговорено і перевірено. Якщо є бажання і потреба, будь-яка ідея буде втілена.

\section{5. Відповідальність}

Принцип Сент-Екзюпері про відповідальність за тих, кого приручили, укупі з переконаннями 
і поглядами педагога приносять свої результати. Зі своїми студентами різних випусків Василь Вiтер створив творче об'єднання «Вітряк»-це театральна платформа для кінопроєктів і театральних постановок на сцені. Тут автори не просто діляться своїми новими ідеями, вони показують високий рівень української культури, широкий діапазон невичерпної творчої та постановочної фантазії, дивовижну працездатність. Вони привертають увагу глядачів яскравими уявленнями, які завжди акцентують традиції української школи, але при цьому постійно рухаються вперед, відкриваючи нові горизонти професійної майстерності. Попри свій молодий вік, творче об'єднання «Вітряк» вже презентувало свої перші театральні роботи в Національному центрі театрального мистецтва імені Л. Курбаса, зокрема: «Мина Мазайло» i «Отак загинув Гуска» М. Куліша, «Безталанна» I. К. Карпенка-Карого, «Фізики» Ф. Дюрренматта, «Одержима» Лесі Українки, постановниками яких є Віталій Савчук, Василь Вітер.

Без сумніву, кожна вистава, насамперед, тримається на тому фундаменті, який заклав режисер. Василь Вітер і Віталій Савчук, керуючись своїми поглядами і світовідчуттям, інтерпретують класичні твори для нового покоління, роблять їх сучасними, використовуючи доцільні стилістичні зміни та новітні технічні можливості, завдяки чому вистави за класичними п'єсами виглядають актуальними, життєвими і цікавими. «Мина Мазайло» і «Отак загинув Гуска»-це комедії, але комічність тут тісно пов'язана із сумом. Ми сміємося над людськими вадами, над людськими спробами щось відстояти, щось переробити, щось змінити, ми сміємося над тими, хто готовий відректися від усього рідного, своєї нації, мови, культури, а проблеми, які піднімаються у виставах, - i українізація, і відносини між батьками і дітьми, і мовна проблема, і невміння відстоювати свою думку, - залишаються невирішеними і до сьогодні. Як відомо, через сміх насущні проблеми народу звучать ще гостріше, і від цього дуже сумно. Творчість українських драматургів Миколи Куліша, Івана Карпенка-Карого, Лесі Українки актуальна сьогодні як ніколи. Драматурги змушують нас думати над тим, як захистити і відстояти свою мову, як відродити українську культуру й історію. У цьому контексті завданням Василя Вітра і Віталія Савчука було пробудити в нас почуття національної самоповаги та власної гідності, вони спонукають нас відроджувати українську мову, українську культуру, а також виховувати свою духовність. I тому ці вистави сприймаєш із задоволенням, на одному диханні, аж до «мурашок» по шкірі.
Ім'я Віталія Савчука в цьому ряду теж не випадкове. Василя Вітра та Віталія Савчука поєднує одне ім'я - Лесь Курбас. Заслужений артист України Віталій Савчук закінчив Харківський інститут мистецтв імені І. Котляревського, навчався у дружини Леся Курбаса Валентини Чистякової. Після закінчення вишу працював актором у театрах: ТЮГ, Київський театр російської драми імені Лесі Українки, український драматичний театр імені Франка, музичний театр для дітей та юнацтва. Зіграв у відомих виставах «Макбет», «Войцек», «Ні з тобою, ні без тебе», «Король Лір» та ін. Згодом почав викладати акторську майстерність у Київському національному університеті театру, кіно і телебачення імені І. К. КарпенкаКарого на курсі у Василя Вітра. Випускник, викладач, режисер Іван Канівець згадує: «Симбіоз Василя Петровича і Віталія Володимировича у плані студентських робіт, вистав давав фантастичний результат, це не просто об'єднання потенціалів, де один плюс один давало два, це “мультиплікація”, коли один плюс один дає десять» (Чхатарашвілі-Петраш I., 2021, з архіву авторки). Віталій Савчук-викладач передавав студентам усі свої знання, які отримав від свого майстра та які здобув у своїй творчій практиці. А головне Віталій Володимирович дотримувався одного правила, щоб «студент через спілкування 3 педагогом народився не тільки як актор чи режисер, але і як духовна особистість - осмислив себе» (Бондарчук Л., 2007, с. 61).

У В. Савчука був прекрасний музичний слух, він міг робити і грати все що завгодно, він віртуозно володів мовою, пластикою, у нього була фантастична природна координація, «він приніс у театральний простір свою індивідуальну барву. <...> проявлялась інша школа-вимогливіша, ближча до Леся Курбаса» (Брюховецька Л., 2020, с. 20). Але насамперед він був Людина - віруюча і духовна.

\section{6. Любов, Терпіння, Віра}

Василь Петрович любить своїх учнів однаково, усіх ні більше, ні менше. Він любить їх незалежно від їхньої зовнішності, здібностей, плюсів і мінусів. I це зовсім не означає, що його любов сліпа, ні: він вірить в їхні творчі можливості. Майстер терплячий і чесний: якщо йому щось подобається у їхній творчій роботі - то обов'язково хвалить, а якщо не подобається - говорить про це прямо, але завжди тактовно й делікатно, щоб не образити студента. Василь Вітер розуміє, що кожен з них по-своєму досягне успіху в своїй професії. Найважливішим його завданням $€$ створення сприятливої атмосфери в студентському колективі, 
«психологічний клімат» в аудиторії, тому що колектив має стати для студентів сім'єю, де їм буде затишно, комфортно і де вони зможуть відчувати себе захищеними.

Педагог не формує універсальну схему навчання - він формує індивідуальні стосунки 3 кожним студентом, обговорюючи проблемні моменти завжди тет-а-тет. Майстер веде своїх студентів 3 першого курсу і до випуску і якщо бачить, що студент відстає, не встигає, гальмує, - ніколи не залишить його, а, навпаки, в скрутну хвилину підтримає, спробує знайти причини цих проблем: поспілкується із самим студентом, 3 його друзями, групою, спробує творчо його стимулювати. У В. Вітра $\epsilon$ виняткова педагогічна риса - він любить розмовляти зі студентом. I в цих розмовах змушує його думати, аналізувати, шукати правду в цьому і полягає справжня педагогіка.

Андрій Кравченко згадує, як терпляче майстри ставляться до творчих пошуків:

Кожен з нас робив невеликий фрагмент із п'єси, намагаючись у своєму “шматочку” виділити основну думку. Перше розуміння п'єси завжди мало бути самостійним. Щоб отримати максимально якісний результат, можна запропонувати кілька своїх варіантів. Потім Василь Петрович і Віталій Савчук не тільки обробляли наші невмілі етюди (уривки), але й вносили свої професійні акторськорежисерські корективи. (Чхатарашвілі-Петраш I., 2021, з архіву авторки).

Постійним терплячим плеканням правильної вимови, реакції, дії, руху майстри допомагали студентам-акторам повертатися до репетиції зі збагаченою і насиченою ідеєю.

В. П. Вітер вірить у сучасну молодь, тому що вона $€$ гарантом відродження культури, освіти, - це майбутнє України. Він говорить:

Наша молодь, в основному, конструктивно налаштована щодо устрою і ладу в Україні. Але вони не сприймають фальші, вміють відрізняти і цінувати справжнє. А ще вони потенційно сильні й талановиті люди. Аби тільки не збилися на манівці. Все своє життя я дивувався і вірив у силу українського селянського духу. От де по-справжньому невичерпна сила оптимізму. (Газета «День», 2010).

Висновки. Підбиваючи підсумок сказаному, слід ще раз наголосити, що Василь Вітер віддає Інституту, а точніше, студентам кращі роки свого творчого життя, він «прикипає» до них серцем, вважаючи їх своїми дітьми, своєю другою сім'єю. Його стиль, метод режисерського мислення, традиції вітрівської школи знайшли гідне продовження у твор- чості його учнів-акторів, учнів-режисерів, яких він навчав і навчає. Життя В. Вітра триває в його студентах, вони стали гідними режисерами, педагогами, працюють на продакшенах, студіях, ТБ-каналах і завжди приходять підтримати майстра, допомогти молодому поколінню. Отже, для того щоб бути справжнім педагогом, потрібно завжди тримати «відкриті очі», добре серце і чистий розум.

\section{Джерела та література}

Безручко, О. (2017). Завершальний етап педагогічної діяльності Михайла Верхацького в Київському державному інституті театрального мистецтва

імені І.К. Карпенка Карого. Студї мистеитвознавчі. Театр. Музика. Кіно : [наук. журн.] ; НАНУ, ІМФЕ ім. М. Т. Рильського. Київ. Чис. 1 (57). С. 82-87.

Брюховецька, Л. (2020). Привид ідеального актора з театру Курбаса. Кіно-Театр. № 6. С. 19-22.

Бондарчук, Л. (2007). Савчук: Актор - категорія радше душевна, ніж духовна. Кіно-Театр. № 3. С. 59-61.

Новорічна анкета газети «День». (2010). / novorichna-anketagazeti-den-vasil-viter / Грудень.

Чхатарашвілі-Петраш I. (2021). Інтерв'ю з випускницею I. Правило. Київ. 26.05. 3 архіву авторки.

Чхатарашвілі-Петраш I. (2021). Інтерв'ю з випускником I. Канівцем. Київ. 21.05. 3 архіву авторки.

Чхатарашвілі-Петраш I. (2021). Інтерв'ю з випускником А. Кравченком. Київ. 22.05. 3 архіву авторки.

Чхатарашвілі-Петраш I. (2021). Інтерв'ю з випускником А. Бортником. Київ. 17.05. 3 архіву авторки.

\section{References}

Bezruchko, O. (2017). Zavershalnyy etap pedahohichnoyi diyalnosti Mykhayla

Verkhatskoho v Kyyivskomu derzhavnomu instytuti teatralnoho mystetstva imeni I.K.Karpenka-Karoho [The final stage of Mykhailo Verkhatsky's pedagogical activity at the Kyiv National I. K. Karpenko-Karyi Theatre, Cinema and Television Institute]. Studiyi mystetstvoznavchi. Teatr. Muzyka. Kino: [nauk. Zhurn.]; NANU, IMFE im. M. T. Ryl's'koho. Kyiv, Chys. 1 (57). S. 82-87.

Briukhovetska, L. (2020). Pryvid idealnoho aktora z teatru Kurbasa [The reason for the ideal actor from the Kurbas Theater]. Kino-Teatr. № 6. S. 19-22.

Bondarchuk, L. (2007). Savchuk: Aktor - katehoriya radshe dushevna, nizh dukhovna [Savchuk: An actor is a spiritual rather than a spiritual category]. Kino-Teatr. №3. S. 59-61.

Novorichna anketa hazety «Den» [New Year's questionnaire of The Day newspaper]/Hruden

Chkhatarashvili-Petrash, I. Intervyu z vypusknytseyu I. Pravylo [Interview with a graduate of Pravylo, I.] Kyiv. 26.05. Z arkhivu avtora.

Chkhatarashvili-Petrash, I. Intervyu z vypusknytseyu I. Kanivtsem [Interview with a graduate of Kanivets, I.]. Kyiv. 21.05. Z arkhivu avtora.

Chkhatarashvili-Petrash, I. Intervyu $z$ vypusknytseyu A.Kravchenko [Interview with a graduate of Kravchenko, A.]. Kyiv. 22.05. $\mathrm{Z}$ arkhivu avtora.

Chkhatarashvili-Petrash, I. Intervyu $z$ vypusknytseyu $A$. Bortnykom [Interview with a graduate of Bortnyk, A.]. Kyiv. 17.05. $\mathrm{Z}$ arkhivu avtora. 


\section{Inha Chkhatarashvili-Petrash}

\section{Vasyl Viter: the art of being a teacher}

Abstract. The article is devoted to the coverage of the pedagogical activity of the famous Ukrainian director V. Viter, which deserves attention no less than his famous films and acting skills. The author analyzes the basic principles of the master's pedagogical system (traditions and rules, self-development, systematics, responsibility, etc.), which allowed to form an original television directing workshop at the I.K. KarpenkoKaryi Institute of Screen Arts of Kyiv National University of Theater, Film and Television. Today, the workshop has grown into a «Viter's school», which can be considered an exemplary model of interaction between teacher and student of art college.

Key words: Vasyl Viter, Vitaliy Savchuk, Viter's school, teacher, workshop, director. 